\title{
PEMANFAATAN SUSU MENJADI OLAHAN YOGURT DAN PEMASARAN ONLINE SEBAGAI SARANA UNTUK MENINGKATKAN PENDAPATAN
}

\author{
Ani Interdiana Candra Sari ${ }^{1}$, Elin Karlina ${ }^{2}$, Alqomari Cahyo ${ }^{3}$ \\ ${ }^{12}$ Pendidikan Ekonomi, FIPPS, Universitas Indraprasta PGRI \\ ${ }^{3}$ Informatika, FTIK, Universitas Indraprasta PGRI
}

\begin{abstract}
Abstrak
Maksud diadakan abdimas ini adalah agar peserta memiliki keterampilan dalam mengolah susu menjadi olahan lain dan mampu memasarkan secara online, khususnya mengolah susu menjadi yogurt dan memiliki jiwa kewirausahaan. Metode yang digunakan adalah observasi, wawancara, dan pelatihan. Berdasarkan penyuluhan yang diadakan diperoleh hasil sebagai berikut: 1) Peserta mampu mengolah susu menjadi yogurt dengan berbagai rasa. 2) Peserta mampu membuat kemasan yang menarik dalam pemasaran. 3) Peserta mampu memasarkan yogurt melalui media sosial. 4) Peserta mampu memotivasi diri dalam pembuatan berbagai olahan dari susu. 5) Peserta didik menunjukkan minat untuk berwirausaha.
\end{abstract}

Kata Kunci: Yogurt, Pemasaran Online, Kreatif, Kewirausahaan

\begin{abstract}
The purpose of this abdimas is that participants have skills in processing milk into other processed products and are able to market online, especially processing milk into yogurt and have an entrepreneurial spirit. The method used is observation, interview, and training. Based on counseling, the following results were obtained: 1) Participants were able to process milk into yogurt with a variety of flavors. 2) Participants are able to make attractive packaging in marketing. 3) Participants are able to market yogurt through social media. 4) Participants are able to motivate themselves in making various preparations from milk. 5) Students show an interest in entrepreneurship.
\end{abstract}

Keywords: Yogurt, Online Marketing, Creative, Entrepreneurship

Correspondence author: Ani Interdiana Candra Sari, incasani26@gmail.com, Jakarta, Indonesia (i) (8)

This work is licensed under a CC-BY-NC

\section{PENDAHULUAN}

Berbagai Produk olahan dari susu sapi yang difermentasikan sudah ada sejak dulu, misalnya susu sapi yang difermentasikan menjadi yogurt. Membiasakan minum yoghurt setiap hari meningkatkan kerja bakteri baik dalam usus manusia. (Sulandari dkk., 2001).

Pembusukan dengan bantuan bakteri merupakan salah satu cara yang digunakan dalam pengawetan makanan atau minuman yang sudah ada dari dulu. Fermentasi dan 
penambahan enzim merupakan suatu cara pengawetan secara biologis dengan bantuan ragi atau mikroba. Bioteknologi berbasis fermentasi dengan menggunakan mikroorganisme yang menghasilkan energi yang berlangsung dengan kondisi anaerobik dan pembebasan gas untuk memproduksi makanan dan minuman seperti: keju, yoghurt, minuman beralkohol, cuka, sirkol, acar, sosis, kecap, dll (Nurcahyo, 2011).

Fermentasi memiliki hakikat proses metabolisme mikroba untuk menghasilkan produk yang memiliki nilai jual tinggi, seperti asam-asam organik, protein sel tunggal, antibiotika dan biopolimer. Fermentasi atau pembusukan merupakan salah satu cara pengawetan yang mudah dengan biaya terjangkau yang telah ada sejak dulu kala. (Muhiddin, dkk).

Banyak cara yang ditempuh untuk menjaga olahan susu agar dapat memberikan nilai tambah dengan bantuan teknologi. Dengan demikian, akan menghasilkan berbagai olahan susu fermentasi seperti yoghurt. Yoghurt adalah produk fermentasi atau pembusukan yang melibatkan jasa mikroorganisme yaitu bakteri. Yoghurt terbuat dari bakteri baik yang bermanfaat bagi kesehatan, seperti Lactobacillus bulgaricus dan Streptococus thermopillus. Kedua bakteri tersebut akan membuat asam laktat yang bermanfaat pada keseimbangan kesehatan usus. Asam laktat yang diciptakan dapat mencegah bakteri penyebab penyakit yang umumnya tidak tahan terhadap asam (Wakhidah, 2017).

Yoghurt terdiri dari 2 rasa, yaitu yoghurt tanpa penambahan rasa (plain yoghurt) dan yoghurt dengan penambahan rasa (flavored yoghurt). Yoghurt dengan aneka rasa akan memberikan rasa yang berbeda dan kesukaan/penerimaan konsumen. Pada umumnya anak-anak lebih suka yoghurt yang ditambahkan citarasa (Mahmood, dkk. 2008 dalam Wulandari, 2010).

Argandhina Purbasari (2014) memaparkan beberapa pendapat para ahli bahwa mutu yogurt dapat diukur dari beberapa paramater, di antaranya adalah $\mathrm{pH}$, kekentalan, citarasa, dan kesukaan. Nilai pH merupakan tingkat keasaman yang dimanfaatkan untuk menyatakan tingkat keasaman atau kebasaan yang dimiliki oleh suatu larutan. Nilai pH dipengaruhi oleh perkembangan mikroba yamg berupa asam laktat dalam proses fermentasi yogurt (Buckle dalam Wakhidah, 2017). Kekentalan susu merupakan kontribusi dari keberadaan kasein/misein dan globula lemak yang terdapat pada susu, selain itu ikatan di antara protein dan lemak dapat memberikan pengaruh terhadap kekentalan, perubahan kasein susu yang mempunyai karakter hidrophilik yang sama dengan jenis protein lain menyebabkan kekentalan meningkat. Asaam laktat yang dihasilkan selama proses fermentasi dapat meningkatkan citarasa dan meningkatkan keasaman atau menurunkan $\mathrm{pH}$-nya. Citarasa bahan makanan atau minuman memiliki 3 unsur yaitu bau, rasa dan rangsangan dari mulut. Secara umum bahan pangan tidak hanya terdiri dari satu macam rasa tetapi campuran dari aneka ragam rasa secara sistematis, sehingga menimbulkan citarasa yang utuh. Citarasa pada yoghurt drink dapat mempengaruhi tingkat kesukaan. Semakin asam citarasa yoghurt yang dihasilkan, semakin berkurang peminat dari konsumen.

Seiring dengan perkembangan teknologi, kegiatan memasarkan produk pun menjadi lebih mudah, yaitu dengan pemasaran internet (online). Banyak manfaat yang diperoleh dari pemasaran online, yaitu tidak terbatas dengan waktu, menjangkau pasar lebih luas, mengurangi biaya pemasaran dan masih banyak hal-hal positif yang di dapat. Oleh sebab itu, pemasaran ini sangat cocok digunakan oleh peserta, karena sangat mudah dilakukan, cukup hanya menggunakan ponsel saja. Jadi disela-sela waktu kosong mereka bisa memanfaatkan waktu untuk berwirausaha. 
Tujuan dari pelatihan ini adalah agar peserta memiliki keterampilan dalam mengolah yogurt dari susu, serta peserta dapat menghasilkan karya-karya cipta dan memiliki jiwa kewirausahaan.

\section{METODE PELAKSANAAN}

Waktu Pelaksanaan kegiatan Akan di selenggarakan pada:

Tabel 1. Waktu dan Tempat Pelaksanaan Abdimas

\begin{tabular}{cccc}
\hline No & Hari, Tanggal & Waktu & Tempat \\
\hline 1 & Minggu, 23 Juni 2019 & $08.00-13.30$ & \multirow{2}{*}{ PUI DKI Jakarta } \\
\hline 2 & Minggu, 30 Juni 2019 & $09.00-12.30$ & \\
\hline
\end{tabular}

Metode yang akan dilakukan dalam kegiatan ini adalah melalui beberapa tahap:

1. Observasi langsung. Tim pengabdian masyarakat mengunjungi tempat yang akan dijadikan objek pengabdian untuk memperolah informasi. Kegiatan tersebut dilaksanakan saat menjelang kegiatan maupun saat kegiatan berlangsung. Pada saat menjelang kegiatan hal yang pertama kali kami lakukan adalah meminta ijin secara informal dengan Ketua Pemuda PUI DKI Jakarta dengan Bapak Fazrin Fadillah menentukan peserta yang akan diberikan pelatihan. Tujuan Observasi ini untuk mendapatkan informasi mengenai kondisi peserta dan lokasi serta untuk mewujudkan kesuksesan kegiatan pengabdian masyarakat itu sendiri.

2. Wawancara. Wawancara kami lakukan dengan Ketua Pemuda PUI DKI Jakarta.

3. Pelatihan, yaitu: tim memberikan pelatihan secara langsung kepada kelompok ibuibu. Pelatihan untuk masing-masing kelompok dilakukan 2 kali tatap muka.. Hal ini dilakukan agar kelompok ibu-ibu mampu memahami cara pembuatan dan cara pemasarannya.

\section{Tahapan Rencana}

Adapun tahapan pelaksanaan program yaitu sebagai berikut:

1. Persiapan

Sebelum pelaksanaan pelatihan tentunya dilakukan persiapan guna kelancaran pelatihan. Persiapan yang kami lakukan antara lain:

a. Survei tempat pelaksanaan kegiatan

b. Merancang Program dan metode Pelatihan

c. Pembuatan materi pelatihan

d. Mengkoordinasikan jadwal pelatihan dengan PUI DKI Jakarta

e. Koordinasi dalam penyediaan fasilitas pelatihan seperti laptop, proyektor dan sarana prasarana

2. Pelaksanaan Pelatihan

Kegiatan pengabdian akan dilaksanakan setelah semua perizinan dan persiapan baik perlengkapan maupun peralatan sudah siap digunakan

a. Target kuota kegiatan pelatihan ini adalah 30 orang. Pelatihan akan dilaksanakan sesuai dengan kesepakatan dengan PUI DKI Jakarta.

b. Pelatihan diselenggarakan dengan teori dan praktik 


\section{Materi Pelatihan}

Pengolahan susu menjadi yogurt tidak begitu sulit, namn memerlukan proses yang lama, sehingga mampu menghasilkan yogurt dengan kualitas yang baik dan memiliki daya saing yang tidak kalah dengan produk lain yang sejenis. Berikut adalah alat dan bahan yang diperlukan untuk membuat yogurt:

1. Bahan dan alat

a. Susu Murni

b. Biang Yogurt

c. Perisa Buah

d. Panci

e. Kompor

f. Gelas (Drinking Jar)

g. Sendok

h. Gunting

i. Karet

j. $\quad$ Plastik ukuran $1 \mathrm{~kg}$

2. Cara membuat:

a. Masukan susu ke dalam panci, lalu diaduk dengan menggunakan api kecil hingga suam-suam kuku (tidak boleh sampai mendidih), kemudian diangkat.

b. Setelah diangkat, diamkan hingga dingin, kemudian masukan biang yogurt sambil diaduk hingga merata.

c. Setelah itu, masukan susu yang sudsh di campur dengan biang yogurt ke dalam drinking jar, lalu tutup rapat dan dilapisi dengan plastik dan di ikat dengan karet gelang, jangan sampai ada udara yang masuk didalamnya.

d. Setelah dikemas dengan rapi, kemudian disimpan di ruangan yang tidak terpapar sinar matahari atau lampu (ruangan gelap), serta tidak boleh terkena guncangan, diamkan selama 24 jam.

e. Setelah 24 jam di ruang gelap, maka yogurt sudah siap di konsumsi. Penyajiannya dingin lebih nikmat dan dapat dicampur dengan perisa rasa buah.

3. Tahap Pengemasan

Yogurt yang sudah jadi, kemudian dikemas dengan menarik, lalu dipasarkan melalui media sosial (wa, IG, dll)

\section{HASIL DAN PEMBAHASAN}

\section{Kegiatan Pendahulu}

1. Perizinan

Pada tanggal 14 Januari 2019 PUI DKI Jakarta telah memberikan surat mitra mengenai kegiatan pengabdian masyarakat, kemudian pada tanggal 24 Maret 2019 PUI DKI Jakarta juga telah memberikan izin untuk dilaksanakannya kegiatan pengabdian masyarakat dengan tema "PKM Kelompok Pemuda Persatuan Ummat Islam Di Pancoran, Jakarta Selatan, DKI Jakarta (pelatihan pemanfaatan susu menjadi olahan yogurt dan pemasaran online sebagai sarana untuk meningkatkan pendapatan)". Akan tetapi, pihak PUI DKI Jakarta memberikan izin untuk pelaksanaan abdimas pada hari libur, dikarenakan pada hari libur mereka tidak ada kegiatan, yaitu pada tanggal 23 Juni 2019 dan tanggal 30 Juni 2019. 
2. Persiapan Pelatihan

Setelah mendapatkan izin dari pihak PUI DKI Jakarta, kami mulai melakukan persiapan dan membuat materi sesuai dengan jumlah peserta yang akan datang mengikuti pelatihan. Dari data yang diperoleh jumlah peserta yang menghadari penyuluhan sebanyak 20 peserta.

\section{Realisasi Kegiatan Pengabdian Masyarakat}

1. Pemberian Materi Pembuatan Yogurt

Materi yang kami berikan adalah materi tentang pembuatan yogurt yang terdiri dari:
a. Mengenal dan memahami berbagai olahan susu, khususnya yogurt
b. Membuat yogurt dari susu sapi
c. Motivasi untuk membiasakan diri menjadi kreatif

2. Pemberian materi mengenai pemasaran online

Materi yang kami berikan, yaitu materi tentang teori mengenai pemasaran secara online dan menjelaskan cara pemasaran melalui media sosial.

Kegiatan pelatihan ini dilaksanakan di PUI DKI Jakarta sebanyak 20 peserta. Pelaksanaan kegiatan Pengabdian pada Masyarakat secara keseluruhan berjalan dengan lancar sesuai dengan rencana yang telah dibuat. Beberapa faktor pendukung pada saat berlangsungnya kegiatan pelatihan sehingga dapat diambil kegunaan pembuatan yogurt ini adalah:

a. Peserta memiliki kemauan yang kuat untuk menambah pengetahuan dan pemahaman mengenai berbagai macam olahan susu, khususnya yogurt. Hal ini dapat dilihat dari antusias peserta dalam mengikuti pelatihan.

b. Peserta memiliki minat dan keinginan untuk membuat produk.

c. Peserta antusias dalam penggunaan media sosial

d. Kegiatan pelatihan ini disambut baik oleh pihak PUI DKI Jakarta yang secara langsung ataupun tidak langsung meminta agar bentuk kegiatan seperti ini diadakan berkesinambungan/berkelanjutan sehingga dapat langsung dirasakan manfaatnya bagi peserta didik. berikut:

Beberapa kendala yang dihadapi pada saat pelatihan berlangsung adalah sebagai

a. Waktu pelatihan terbatas.

b. Adanya keterbatasan dalam fasilitas pendukung untuk melakukan pelatihan, hal ini dikarenakan praktek pembuatan yogurt dengan alat yang terbatas jumlahnya.

c. Pelaksanaan Kegiatan Pelatihan Pembuatan Yogurt

Tabel 2 Jadwal Pelaksanaan Kegiatan Pembuatan Yogurt

\begin{tabular}{ccccc}
\hline No & Hari, Tanggal & Waktu & Kegiatan & Keterangan \\
\hline 1 & Minggu, 23 Juni & $08.00-13.30$ & $\begin{array}{c}\text { Menyampaikan } \\
\text { materi dan proses } \\
\text { pembuatan yogurt }\end{array}$ & Tim Abdimas \\
\hline 2019 & Minggu, 30 Juni & $09.00-12.30$ & $\begin{array}{c}\text { Menyampaikan } \\
\text { materi pemasaran } \\
\text { online dan cara } \\
\text { memasarkan yogurt } \\
\text { 2019 }\end{array}$ & Tim Abdimas \\
& & & \\
& & & \\
& & & \\
& & &
\end{tabular}




\section{Hasil Pelatihan}

Pelaksanaan pengabdian masyarakat mengenai pelatihan Pembuatan Yogurt dan pemasaran Online bagi masyarakat di PUI DKI Jakarta, dilakukan oleh tim yang berjumlah 3 orang dari universitas Indraprasta PGRI. Tempat pelatihan dilaksanakan di PUI DKI Jakarta.

Bersumber dari penyuluhan yang telah diadakan diperoleh hasil sebagai berikut:

1. Peserta telah mampu mempraktekan pembuatan yogurt

2. Peserta mampu membuat kemasan yang menarik dalam pemasaran

3. Peserta mampu memasarkan yogurt melalui media sosial

4. Peserta mampu memotivasi diri dalam pembuatan yogurt

5. Peserta menunjukkan minat untuk berwirausaha

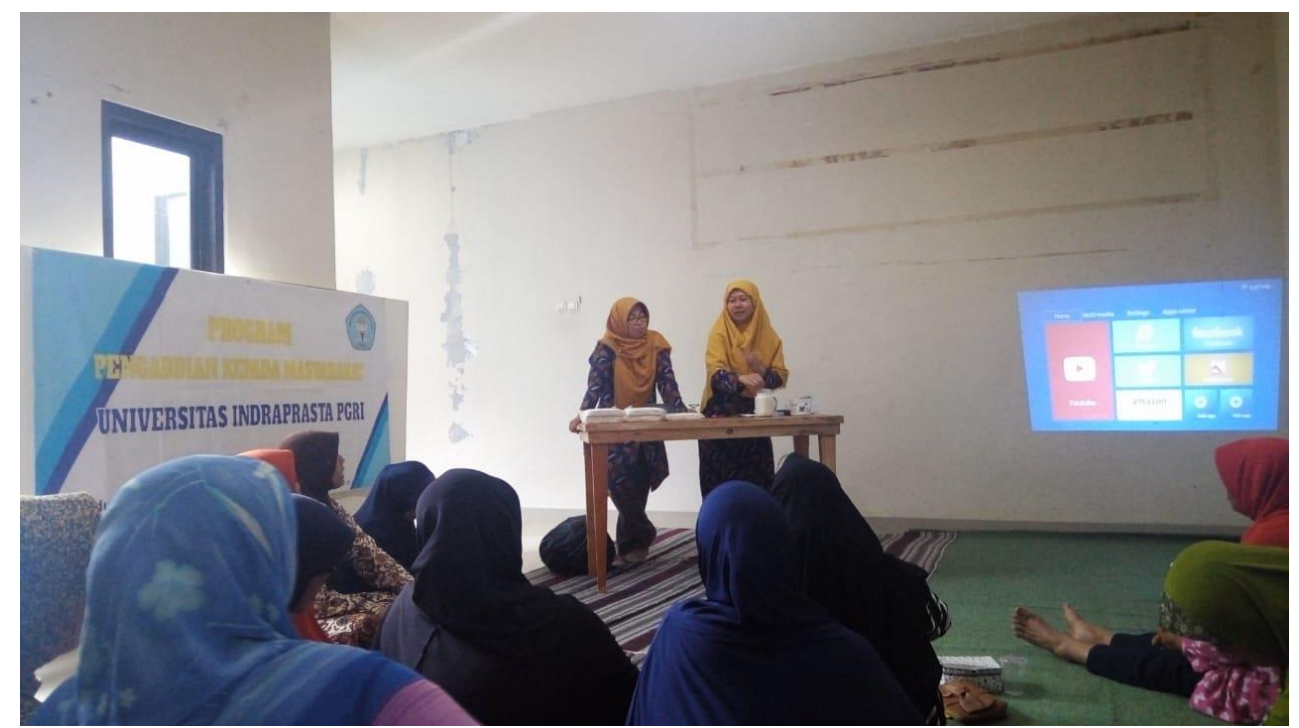

Gambar 1 Foto kegiatan: Memaparkan materi

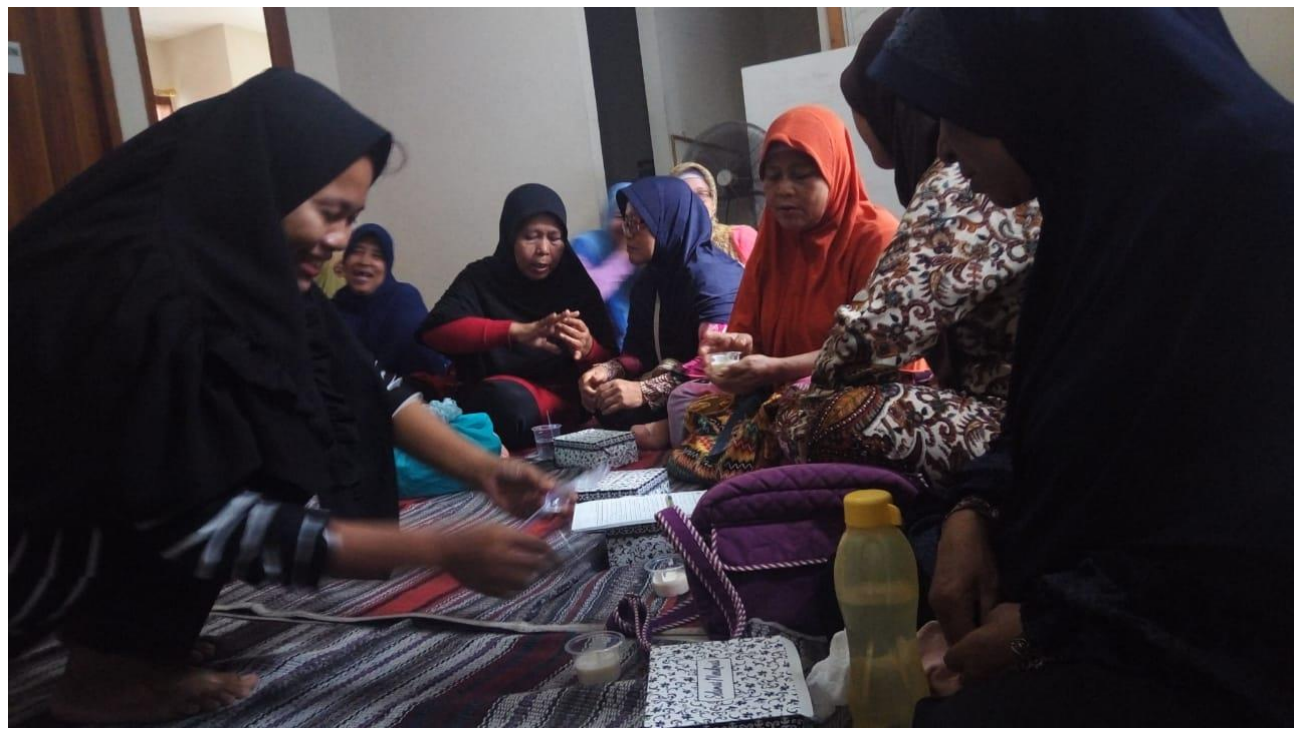

Gambar 2 Foto Kegiatan: Peserta Mempraktekan Pembuatan Yoghurt 


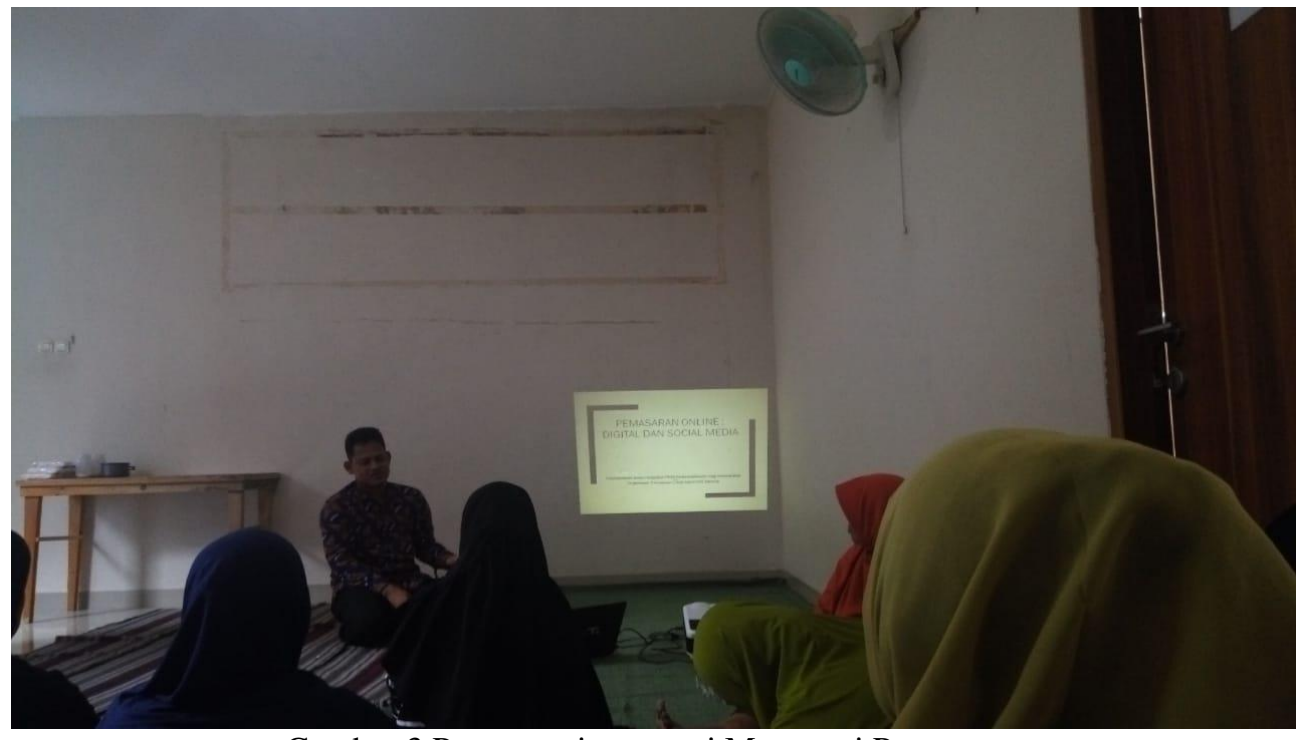

Gambar 3 Penyampaian materi Mengenai Pemasaran
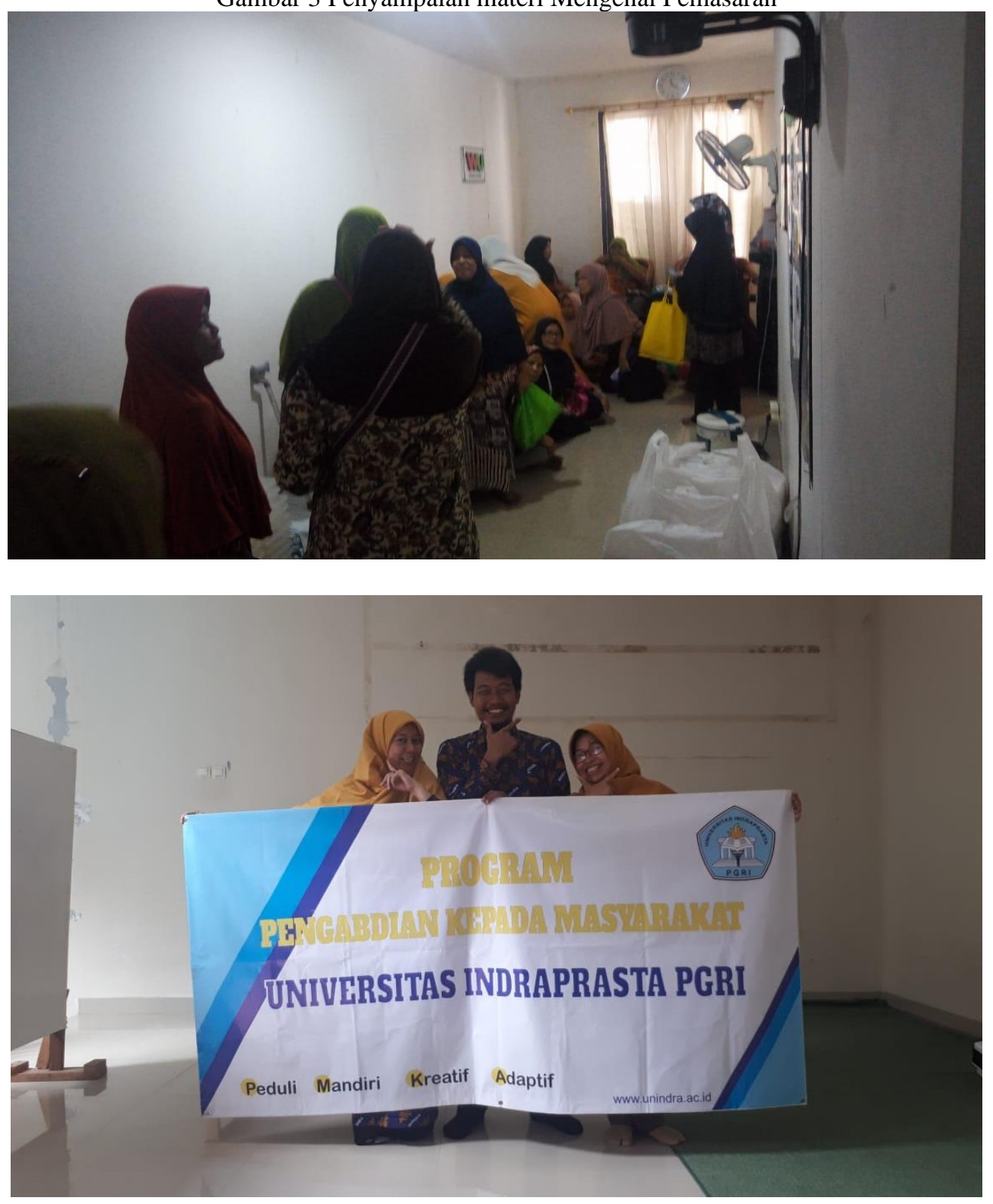


\section{SIMPULAN}

Dari kegiatan Program Pengabdian Masyarakat yang telah kami laksanakan di PUI DKI Jakarta, maka ada beberapa hal yang kami simpulkan yaitu:

1. PKM Kelompok Pemuda Persatuan Ummat Islam Di Pancoran, Jakarta Selatan, DKI Jakarta (pelatihan pemanfaatan susu menjadi olahan yogurt dan pemasaran online sebagai sarana untuk meningkatkan pendapatan) berdasarkan hasil umpan balik didapatkan informasi bahwa kegiatan ini sangat relevan dengan kebutuhan para peserta untuk menambah pendapatan, selain itu peserta bisa memanfaatkan waktu luang untuk kegiatan yang menghasilkan atau belajar menjadi wirausahawan.

2. Besarnya minat peserta untuk mengikuti pelatihan dan pemasaran pembuatan yogurt secara Online, namun tidak diimbangi dengan daya dukung dan ketersediaan waktu yang cukup singkat.

\section{DAFTAR PUSTAKA}

Muhiddin, N. H., Juli, N., \& Aryantha, I. N. P. (2001). Peningkatan kandungan protein kulit umbi ubi kayu melalui proses fermentasi. JMS, 6(1), 1-12.

Nurcahyo, H. (2011). Diktat Bioteknologi. Yogyakarta: Universitas Negeri Yogyakarta

Purbasari, A., \& Abduh, S. B. M. (2013). Nilai pH, kekentalan, citarasa, dan kesukaan pada susu fermentasi dengan perisa alami jambu air (Syzygium Sp). Jurnal Aplikasi Teknologi Pangan, 3(4).

Sulandari, L., Kumalaningsih, S., \& Susanto, T. (2001). Penambahan Ekstrak Tempe untuk Mempertahankan Viabilitas Bakteri Asam Laktat pada Yoghurt Bubuk. Jurnal Biosains.

Wakhidah, N., Jati, G., \& Utami, R. (2017). Yoghurt Susu Sapi Segar dengan Penambahan Ekstrak Ampas Jahe dari Destilasi Minyak Atsiri. In Proceeding Biology Education Conference: Biology, Science, Enviromental, and Learning (Vol. 14, No. 1, pp. 278-284). 